\title{
Annual Report 1999
}

\section{E nvironmental Dynamics and Simulation}

J. M. Zachara, Associate Director and the Staff of the Environmental Dynamics and Simulation Directorate

June 2000

Prepared for the U.S. D epartment of Energy under Contract DE-AC06-76RLO 1830 


\title{
DISCLAIMER
}

This report was prepared as an account of work sponsored by an agency of the United States Government. Neither the United States Government nor any agency thereof, nor Battelle Memorial Institute, nor any of their employees, makes any warranty, express or implied, or assumes any legal liability or responsibility for the accuracy, completeness, or usefulness of any information, apparatus, product, or process disclosed, or represents that its use would not infringe privately owned rights. Reference herein to any specific commercial product, process, or service by trade name, trademark, manufacturer, or otherwise does not necessarily constitute or imply its endorsement, recommendation, or favoring by the United States Government or any agency there of, or Battelle Memorial Institute. The views and opinions of authors expressed herein do not necessarily state or reflect those of the United States Government or any agency thereof.

\author{
PACIFIC NORTHWEST NATIONAL LABORATORY \\ operated by \\ BATTELLE \\ for the \\ UNITED STATES DEPARTMENT OF ENERGY \\ under Contract DE-AC06-76RLO 1830
}

Printed in the United States of America

Available to DOE and DOE contractors from the

Office of Scientific and Technical Information, P.O. Box 62, Oak Ridge, TN 37831;

prices available from (615) 576-8401.

Available to the public from the National Technical Information Service,

U.S. Department of Commerce, 5285 Port Royal Rd., Springfield, VA 22161

This document was printed on recycled paper.

$(9 / 97)$ 


\section{Contents}




\section{Introduction}

EMSL Research $1-1$

Research Capabilities $1-2$

Accessing the EMSL $1-2$

Mission of the Environmental Dynamics and Simulation Directorate

\section{Modeling/Simulation}

The Free Energies of Reactions of Chlorinated Methanes with Aqueous Monovalent Anions: Application of Ab Initio Electronic Structure Theory $^{(a)}$

E. J. Bylaska, D. A. Dixon, and

A. R. Felmy

Mixed Hamiltonian Methods for Geochemical Electronic Structure Studies ${ }^{(a)}$

E. J. Bylaska, J. R. Rustad, and M. Dupuis

Application of Pitzer's Equations for Modeling the Aqueous Thermodynamics of Actinide Species in Natural Waters: A Review ${ }^{(\mathrm{e})}$

A. R. Felmy and D. Rai.

Non-Equilibrium Thermodynamic Simulation of Metal Uptake in the Bacterial Electrical Double Layer ${ }^{(a)}$

E. Wasserman, A. R. Felmy, and

A. Chilakapati.

Ab Initio Calculation of Homogeneous Outer Sphere Electron Transfer Rates: Application to $\mathrm{M}\left(\mathrm{OH}_{2}\right)_{6}{ }^{3+/ 2+}$ Redox Couples ${ }^{(\mathrm{d})}$

K. M. Rosso and J. R. Rustad.

Thermodynamics and Kinetics of Cation

Exchange in Micas: Development of

Molecular Modeling Approaches ${ }^{(a)}$

K. M. Rosso and E. J. Bylaska.

Molecular Simulation of Oxide Surface

Chemistry $^{(\mathrm{d})}$

J. R. Rustad, E. J. Bylaska, D. A. Dixon,

A. R. Felmy, and K. M. Rosso. 2-12

Molecular Dynamics Simulations of Hydrated Silicate Liquids and Glasses ${ }^{(\mathrm{b}, \mathrm{d})}$

F. J. Serpa and J. R. Rustad.... 2-15

\section{Spectroscopy/Microscopy}

A Spectroscopic Study of Phenanthrene Adsorption on Porous Silica ${ }^{(b, t)}$

Z. Wang, D. M. Friedrich, M. R. Beversluis,

A. G. Joly, M. H. Huesemann, M. J. Truex,

R. G. Riley and C. J. Thompson and

B. M. Peyton.

Competitive Trace-Level Sorption of Chromate and Phosphate to Hematite Surfaces: A Spectroscopic Approach ${ }^{(\mathrm{e})}$

N. S. Foster-Mills, J. E. Amonette,

B. K. William, and A. E. Taylor

Mössbauer Spectroscopic Study of Iron

Redox in Silicate Glasses ${ }^{(b, e, t)}$

R. K. Kukkadapu, G. L. Smith, H. Li,

J. V. Crum, M. C. Weinberg, and

H. Poisl

Mineralization Processes Associated with the Bacterial Reduction of Fe(III) Oxides ${ }^{(\mathrm{m})}$

J. M. Zachara, J. K. Fredrickson,

Y. A. Gorby, S. C. Smith, and

R. K. Kukkadapu

Redox Chemistry at Mineral Surfaces ${ }^{(\mathrm{a}, \mathrm{b}, \mathrm{m})}$

J. E. Amonette, K. M. Rosso,

Y. A. Gorby, H. R. Divanfard,

J. F. Marquez, E. A. Rodriguez,

and C. K. Russell.

Electron Paramagnetic Resonance Studies of

Mineral Surface Chemistry ${ }^{(b)}$

J. E. Amonette, R. K. Kukkadapu,

A. S. Lea, C. J. Matocha, D. L. Sparks,

W. F. Bleam, and S. J. Yoon.

Geochemical Mechanisms in Terrestrial

Carbon Sequestration ${ }^{(b, c)}$

J. E. Amonette, J. A. Capp, A. Lüttge,

D. R. Baer, and R. S. Arvidson.

Corrosion Products of Mild Steel in High Ionic

Strength Brines and the Effect on Pu(VI)

Reduction $^{(\mathrm{b}, \mathrm{u})}$

Z. Wang, R. C. Moore, A. R. Felmy,

M. Mason and R. K. Kukkadapu 3-28 
Mineral Structure Controls on Cs Adsorption in Hanford Sediments ${ }^{(\mathrm{e})}$

J. M. Zachara, J. P. McKinley,

R. J. Serne, S. C. Smith, and

P. L. Gassman 3-31

\section{Capability Reviews}

Laser Photoacoustic Spectroscopy: Basic and Applied Research ${ }^{(a, b, f, h)}$

N. S. Foster-Mills, J. E. Amonette,

T. Autrey, J. R. Small, Yu Chen, and

E. Small

Mössbauer Spectroscopy

R. K. Kukkadapu and J. E. Amonette ..... 4-6

Commissioning and Initial Results from the

PNC-CAT Insertion Device Beamline at the Advanced Photon Source ${ }^{(\mathrm{d}, \mathrm{f})}$

S. M. Heald, D. L. Brewe, J. O. Cross,

E. D. Crozier, D. Jiang, and

E. A. Stern.

\section{Appendix}

Environmental Dynamics and

Simulation Staff $5-1$

Publications and Presentations 1999 $5-4$

Publications $5-4$

In Press $5-6$

Patents $5-7$

Presentations $5-7$

Honors and Recognition $5-11$

Collaborations $5-12$

External Collaborations $5-12$

Collaborations within PNNL $5-14$

Acronyms and Abbreviations $5-16$

Where ED\&S Fits in PNNL $5-17$

\section{Funding Support}

(a) Pacific Northwest National Laboratory (PNNL) Laboratory Directed Research and Development (LDRD)

(b) EMSL Operations, supported by DOE Office of Biological and Environmental Research (OBER)

(c) National Science Foundation

(d) DOE Office of Basic Energy Sciences (BES)

(e) DOE Environmental Management Science Program (EMSP)

(f) National Science Foundation

(g) DOE-Experimental Program to Stimulate Competitive Research (EPSCoR)

(h) National Institutes of Health

(i) U.S. Department of Agriculture

(j) Laboratory Technology Research (LTR) Program

(k) Motorola, Inc.

(l) Defense Advanced Research Projects Agency (DARPA)

(m) Natural and Accelerated Bioremediation Research Program (NABIR)

(n) DOE Office of Industrial Technologies, Industry of the Future Program, Forest Products

(o) University of Western Sydney (UWS) Nepean Staff Development Fund

(p) Environmental and Health Sciences Division (EHSD)

(q) DOE Energy Efficiency Office of Advanced Automotive Technology

(r) Cooperative Research and Development Agreement (CRADA)

(s) National Aeronautics and Space Administration (NASA)

(t) DOE Office of Science

(u) DOE WIPP Program 